\title{
Epidemiological features of patients with nonsyndromic cleft lip and/or palate in Western Parana
}

\author{
Helenara Salvati Bertolossi Moreira ${ }^{1,2}$, Renato Assis Machado¹, Sibele Nascimento de Aquino ${ }^{3}$, Ana Lúcia Carrinho \\ Ayrosa Rangel ${ }^{2}$, Herćilio Martelli Júnior ${ }^{1,4}$, Ricardo Della Coletta ${ }^{1}$
}

\begin{abstract}
${ }^{1}$ Universidade Estadual de Campinas - UNICAMP, Piracicaba Dental School, Department of Oral Diagnosis, Piracicaba, SP, Brazil
2Universidade Estadual do Oeste do Paraná - UNIOESTE, Department of Physiotherapy, Cascavel, PR, Brazil ${ }^{3}$ Universidade Federal de Juiz de Fora - UFJF, School of Dentistry, Area of Stomatology Clinic, Governador Valadares, MG, Brazil ${ }^{4}$ Universidade Estadual de Montes Claros - UNIMONTES, Dental School, Area of Stomatology Clinic, Montes Claros, MG, Brazil
\end{abstract}

Received for publication: April 11, 2016 Accepted: June 15, 2016

Correspondence to: Renato Assis Machado Department of Oral Diagnosis School of Dentistry, UNICAMP CEP 13414-018, Piracicaba, São Paulo, Brazil Phone: +55 1921065315 E-mail: renatoassismachado@yahoo.com.br

\begin{abstract}
Aim: : To describe the clinical, demographic and environmental features associated with NSCL/P (nonsyndromic cleft lip and/or palate) patients born in western Parana state, Brazil. Methods: This cross-sectional, observational, retrospective study included 188 patients attended at the Association of Carriers of Cleft Lip and Palate - APOFILAB, Cascavel-Parana, between 2012 and 2014. Information on demographic characteristics, medical and dental histories and life style factors were obtained from records and personal interviews. Results: Among the 188 patients, cleft lip and palate (CLP) was the most frequent subtype (55.8\%), followed by cleft lip only (CLO, 25.0\%) and cleft palate only (CPO, 19.2\%). Caucasian males were the most affected, although no differences among types of cleft were observed. The otorhinolaryngologic and respiratory alterations were the most frequent systemic alterations in NSCL/P patients, and more than $80 \%$ of the NSCL/P mothers reported no vitamin supplements during the first trimester of pregnancy. Conclusions: This study revealed that the prevalence of nonsyndromic oral cleft types in this cohort was quite similar to previously reported prevalence rates. Systemic alterations were identified among $23.4 \%$ of the patients and patients with CLP were the most affected. History of maternal exposition to environmental factors related to nonsyndromic oral clefts was frequent and most mothers reported no vitamin supplements during the pregnancy. This study highlights the importance of identifying systemic alterations and risk factors associated with NSCL/P in the Brazilian population for planning comprehensive strategies and integrated actions for the development of preventive programs and treatment.
\end{abstract}

Keywords: Cleft Lip. Epidemiology. Risk factors.

\section{Introduction}

Nonsyndromic cleft lip and/or palate (NSCL/P) represents the most frequent head and neck congenital malformations in the world ${ }^{1,2}$. They are traditionally divided in cleft lip only (CLO), cleft lip and palate (CLP) and cleft palate only (CPO). However, as there are similarities in both epidemiologic features and embryologic timing for both CLO and CLP, they are considered variants of the same defect and grouped together to form the group cleft lip with or without cleft palate $(\mathrm{CL} \pm \mathrm{P})$. The incidence of NSCL/P is approximately 1 in 500-2500 live births and influenced by ethnic and environmental 
factors $^{3,4}$. In Brazil, epidemiological studies demonstrated that the incidence of NSCL/P varies from 1 per 685 to 2800 births $^{5,6}$. Approximately $70 \%$ of $\mathrm{CL} \pm \mathrm{P}$ and $50 \%$ of $\mathrm{CPO}$ are isolated defects and the remaining are related to syndromes including clefts in the clinical spectrum ${ }^{7,8}$. The etiology of NSCL/P, which involves both genetic and environmental factors, is highly complex and the molecular basis remains largely unknown $n^{3,9,10}$. Epidemiological and experimental data suggest the exposure to tobacco smoke, agrotoxics, alcohol, poor nutrition and drugs as the main environmental factors to the development of oral clefts $^{2,11,12}$. On the other hand, maternal ingestion of folic acid or multivitamins during early pregnancy can reduce the risk of NSCL/ $/ \mathrm{P}^{13-15}$.

$\mathrm{NSCL} / \mathrm{P}$ results in morphological and functional morbidities associated with nutrition, speech, hearing, psychological and social aspects and imposes a substantial financial burden ${ }^{3,16}$. Several of the NSCL/P effects may extend into adulthood like an increased risk of cancer ${ }^{17-19}$. Previous studies have also shown a high risk of cancer in relatives of patients with $\mathrm{NSCL} / \mathrm{P}^{18,20}$. This association has been explained, because cancer and NSCL/P may share similar genetic defects, which may be segregated within family ${ }^{21,22}$.

The aim of the present study was to report the epidemiological and clinical features of 188 patients with NSCL/P from western Parana state, Brazil, and to evaluate the family background relevant to the disease.

\section{Material and methods}

This observational cross-sectional study comprised a population of 188 patients with NSCL/P treated at a reference association in Cascavel-Parana, Brazil. This reference service has a multidisciplinary team of health care specialists, including plastic surgeons, dentists, psychologists, physiotherapists, pediatricians, nutritionists and speech therapist. Patients were enrolled between 2012 and 2014 and all subjects were born in the study area. Experienced professionals evaluated the patients and only those identified with nonsyndromic oral cleft were included in this study. Mothers of NSCL/P patients were interviewed and physical examination of the patients was made to establish the subtype of cleft and involved anatomical structures. The incisive foramen was the reference structure to classify nonsyndromic oral clefts. Clefts were also classified by laterality and extent ${ }^{23}$.

Information on demographic characteristics, medical and dental histories and life style factors were obtained from medical records and personal interviews by a trained staff. The variables included gender, age, race/ethnicity, oral cleft type, systemic alterations, mother's exposure to environmental factors, family history and parental consanguinity. Race/ethnicity was established by a multivariate evolution based on skin color in the medial part of the arm, and hair color and texture as previously described ${ }^{24}$.

All mothers of NSCL/P patients were asked about their habits during pregnancy. They were considered smokers or to consume alcohol during the first trimester of pregnancy if any smoking or alcohol consumption was reported. Maternal passive smoking was defined as being exposed to the smoke from more than one cigarette per day at home or at the workplace during the first trimester. The same is true for indirect contact with agrotoxics. Positive exposure was considered when the person had environmental contact with agrotoxics or living near places with constant pesticide spraying ${ }^{25}$. Direct contact with paints, solvents, fuel or laboratory substances were considered as other substances. Mothers who used drugs like antibiotics, anticonvulsants or corticosteroids during the first trimester of pregnancy were classified as positive contact. Data on vitamin supplement intake were also derived from the interview. Women were asked whether they used multivitamins or folic acid supplements during the onemonth preconceptional period or first trimester. Written informed consents were obtained from all participants, and the study was carried out with approval of the institutional Human Research Ethics Committee of the University (071/2012).

Statistical analysis was performed using the GraphPad Prism software version 6.01 for Windows with a 5\% significance level. Chi-square tests assessed the frequency distributions of clinical, demographic and environmental characteristics with the subtypes of cleft.

\section{Results}

A description of study participants is in Table 1. Among the 188 patients, $121(64.4 \%)$ were male, resulting in a male to female 1.8:1 ratio. All types of oral clefts were more frequent in males. The median age of the patients at the first visit was 13 years. Except for a few patients all were classified as Caucasian. Bilateral clefts were significantly more frequent in CLP patients $(33.3 \%)$ than in CLO patients $(4.3 \%, p=0.0001)$ and clefts with complete extent were significantly more common in CLP compared to CLO and CPO $(p=0.0001)$.

Forty-four patients presented diagnosed systemic alterations associated with NSCL/P. Thirty-five patients had only 1 systemic alteration, whilst 9 of the nonsyndromic cleft patients had 2 or more alterations. Otorhinolaryngologic and respiratory alterations were most frequent among NSCL/P patients (Table 2). Palate involvement was essential for otorhinolaryngologic alterations, since patients with CLO did not exhibit any associated alteration in the ears, nose or throat. Allergic bronchitis was the most common associated alteration, more frequent in patients with CLO and CLP (Table 2).

Table 3 depicts the rates of maternal exposure to environmental factors during the first trimester of pregnancy. In general, no significant differences were detected among the NSCL/P groups regarding environmental factors, but the frequency of mothers that did not take vitamin supplements was very high. More than $80 \%$ of the mothers reported no vitamin supplements during the first trimester of pregnancy. No mother reported preconceptional use of vitamins or folic acid. According to Table 4, consanguinity and history of miscarriages and stillbirths were not significantly different among the three types of cleft. Similarly, no significant differences were observed regarding presence of orofacial cleft and cancer in the first degree relatives. 
Table 1 - Distribution by gender and race and clinical extent of the clefts.

\begin{tabular}{lcccc}
\hline & $\begin{array}{c}\text { Cleft lip } \\
\mathrm{n}(\%)\end{array}$ & $\begin{array}{c}\text { Cleft lip and palate } \\
\mathrm{n}(\%)\end{array}$ & $\begin{array}{c}\text { Cleft palate } \\
\mathrm{n}(\%)\end{array}$ & p value \\
Gender & & & & \\
Male & $30(63.8)$ & $69(65.7)$ & $22(61.1)$ & \\
Female & $17(36.2)$ & $36(34.3)$ & $14(38.9)$ & 0.88 \\
\hline Age & & & & \\
0-2 years & $2(4.3)$ & $7(6.7)$ & 0 & \\
2-12 years & $27(57.5)$ & $49(46.7)$ & $25(69.4)$ & \\
13--20 years & $8(17.0)$ & $33(31.4)$ & $9(25.0)$ & \\
>20 years & $10(21.2)$ & $16(15.2)$ & $2(5.6)$ & 0.08 \\
\hline Race/ethnicity & & & & \\
Caucasian & $42(89.4)$ & $93(88.6)$ & $32(88.8)$ & \\
Non-Caucasian & $5(10.6)$ & $12(11.4)$ & $4(11.2)$ & 0.98 \\
\hline Cleft side & & & & \\
Unilateral & $45(95.7)$ & $70(66.3)$ & 0 & 0.0001 \\
Bilateral & $2(4.3)$ & $35(33.3)$ & 0 & \\
\hline Cleft extent & & & $18(50.0)$ & \\
Incomplete & $25(53.2)$ & $18(17.2)$ & $18(50.0)$ & 0.0001 \\
Complete & $22(46.8)$ & $87(82.8)$ & & \\
\hline
\end{tabular}

Table 2 - Distribution of systemic alterations in patients with nonsyndromic cleft lip and/or palate.

\begin{tabular}{|c|c|c|c|}
\hline & $\begin{array}{l}\text { Cleft lip } \\
\mathrm{n}(\%)\end{array}$ & $\begin{array}{c}\text { Cleft lip and palate } \\
n(\%)\end{array}$ & $\begin{array}{c}\text { Cleft palate } \\
n(\%)\end{array}$ \\
\hline \multicolumn{4}{|l|}{ Otorhinolaryngology } \\
\hline Otitis & 0 & $5(16.7)$ & $5(22.7)$ \\
\hline Tonsillitis & 0 & $4(13.3)$ & $4(18.2)$ \\
\hline Allergic rhinitis & 0 & $3(10.0)$ & $4(18.2)$ \\
\hline Sinusitis & 0 & 0 & $2(9.1)$ \\
\hline Pharyngitis & 0 & $1(3.3)$ & 0 \\
\hline \multicolumn{4}{|l|}{ Respiratory } \\
\hline Allergic bronchitis & $3(27.3)$ & $7(23.3)$ & $3(13.6)$ \\
\hline Recurrent pneumonia & $1(9.1)$ & $1(3.3)$ & $1(4.5)$ \\
\hline \multicolumn{4}{|l|}{ Cardiovascular } \\
\hline Benign heart murmur & $2(18.2)$ & $2(6.7)$ & $2(9.1)$ \\
\hline \multicolumn{4}{|l|}{ Dermatologic } \\
\hline Allergic dermatitis & $1(9.1)$ & $3(10.0)$ & 0 \\
\hline \multicolumn{4}{|l|}{ Gastrointestinal } \\
\hline Reflux & $2(18.2)$ & $1(3.3)$ & 0 \\
\hline \multicolumn{4}{|l|}{ Neurological } \\
\hline Seizure & 0 & $2(6.7)$ & 0 \\
\hline \multicolumn{4}{|l|}{ Ophthalmic } \\
\hline Visual deficiency & 0 & $1(3.3)$ & $1(4.5)$ \\
\hline \multicolumn{4}{|l|}{ Musculoskeletal } \\
\hline Scoliosis & $1(9.1)$ & 0 & 0 \\
\hline \multicolumn{4}{|l|}{ Facial } \\
\hline Facial asymmetry & $1(9.1)$ & 0 & 0 \\
\hline Total & $11(17.5)$ & $30(47.6)$ & $22(34.9)$ \\
\hline
\end{tabular}

\section{Discussion}

Different studies were conducted worldwide to evaluate NSCL/P distribution, often resulting in varying prevalence rates $^{26,27}$. However, in most studies, the percentage of patients with CLP is higher compared to that of CLO or CPO ${ }^{28-30}$. Similar results were described in previous studies with Brazilian NSCL/P patients $^{29,31}$. In the present study, the findings revealed $105(55.8 \%)$ patients with CLP, 47 (25\%) with CLO and 36 (19.2\%) with $\mathrm{CPO}$. Moreover, in some studies were observed differences in the distribution of NSCL/P between males and females ${ }^{28,29}$. This study showed that CLO, CLP and CPO prevailed in males. Investigating the epidemiological features of NSCL/P patients treated at the Center for Rehabilitation of Craniofacial Anomalies in Minas Gerais, Brazil, Martelli-Junior et al. (2008) revealed prevalence of CPO in females, whereas males were more affected by other types of cleft $^{32}$.

Unilateral involvement was more common than bilateral in CLO and CLP patients. However, according to the literature, frequency of bilateral CLP is significantly higher than bilateral $\mathrm{CLO}^{28,33,34}$. In addition, patients with bilateral CLP presented more frequently nasal deformities and nasopharyngeal depths than unilateral CLP ${ }^{35,36}$. Involvement of the palate in patients with oral cleft is related to facial and airway structures disruption and in an increased risk of sleep and breathing disorders ${ }^{37}$. In this study, complete CLP was significantly more frequent than complete CLO or CPO.

According to the literature, alterations in NSCL/P patients are complex and beyond the facial structure. Feeding difficulties, speech alterations, recurrent middle ear infections and other difficulties are frequently observed ${ }^{3,28}$. In this study, $23.4 \%$ of oral cleft patients had at least one associated systemic alteration. The highest incidence of systemic alterations was observed in CLP patients. Generally, the most anomalies occur in cases involving the palate rather than the lip and higher rates of hospitalization before age two in children with CP or CLP are reported ${ }^{38}$. In a study of 5,449 cases from 23 European birth registries, anomalies were found in $20.8 \%$ of CLO patients and in $34.0 \%$ of CLP patients ${ }^{39}$, and another study found anomalies in $12.2 \%$ of CLO patients, $35.1 \%$ with CLP and $36.7 \%$ with $\mathrm{CPO}^{38}$. This study confirmed that associated otorhinolaryngologic, respiratory and cardiovascular defects are frequent ${ }^{38,40,41}$. Children born with cleft palate may need more attention and closer monitoring for a long time.

Many studies have identified a relationship between environmental risk factors and NSCL/ $/ \mathrm{P}^{2,11,12}$. Although cigarette smoking, alcohol consumption (drinking) and exposure to agrotoxics among the mothers were the most common environmental factors, the present results showed no differences among types of cleft. With respect to lack of association between environmental factors of parents and risk for orofacial cleft in this study, in contrast to other studies ${ }^{11,42,43}$. The current data support the possibility that exposure to risk factors has a different effect on cleft risk among parents, which may reflect a role for genetic susceptibility factors in cleft development ${ }^{9,44}$. In this study, over two-thirds of mothers did not take vitamin supplements in early pregnancy. Low concentrations of micronutrients increase significantly the risk of orofacial cleft $\mathrm{ft}^{45}$. Recent reports suggest that 
Table 3 - Frequency of maternal exposure to environment factors during the first trimester of pregnancy, according to patients with nonsyndromic cleft lip and/or palate.

\begin{tabular}{|c|c|c|c|c|}
\hline & $\begin{array}{l}\text { Cleft lip } \\
\mathrm{n}(\%)\end{array}$ & $\begin{array}{c}\text { Cleft lip and palate } \\
n(\%)\end{array}$ & $\begin{array}{c}\text { Cleft palate } \\
\mathrm{n}(\%)\end{array}$ & $p$ value \\
\hline \multicolumn{5}{|l|}{ Cigarette smoking } \\
\hline No & $40(85.1)$ & $93(88.6)$ & $30(83.3)$ & \\
\hline Yes & $7(14.9)$ & $12(11.4)$ & $6(16.7)$ & 0.67 \\
\hline \multicolumn{5}{|l|}{ Passive smoking } \\
\hline No & $44(93.6)$ & $92(87.6)$ & $34(94.4)$ & \\
\hline Yes & $3(6.4)$ & $13(12.4)$ & $2(5.6)$ & 0.33 \\
\hline \multicolumn{5}{|l|}{ Alcohol consumption } \\
\hline No & $43(91.5)$ & $99(94.3)$ & $33(91.7)$ & \\
\hline Yes & $4(8.5)$ & $6(5.7)$ & $3(8.3)$ & 0.76 \\
\hline \multicolumn{5}{|l|}{ Illicit drugs } \\
\hline No & $46(97.9)$ & $105(100)$ & $36(100)$ & \\
\hline Yes & $1(2.1)$ & 0 & 0 & 0.22 \\
\hline \multicolumn{5}{|l|}{ Drugs (medications) } \\
\hline No & $39(83.0)$ & $97(92.4)$ & $30(83.3)$ & \\
\hline Yes & $8(17.0)$ & $8(7.6)$ & $6(16.7)$ & 0.14 \\
\hline \multicolumn{5}{|l|}{ Chemicals } \\
\hline Non-exposure & $39(83.0)$ & $74(70.5)$ & $28(77.8)$ & \\
\hline Agrotoxics & $1(2.1)$ & $12(11.4)$ & $4(11.1)$ & \\
\hline $\begin{array}{l}\text { Environment contact } \\
\text { with agrotoxics }\end{array}$ & $4(8.5)$ & $14(13.3)$ & $4(11.1)$ & \\
\hline Other & $3(6.4)$ & $5(4.8)$ & 0 & 0.34 \\
\hline \multicolumn{5}{|c|}{ Vitamin supplementation } \\
\hline No & $37(78.7)$ & $89(84.8)$ & $25(69.4)$ & \\
\hline Yes & $10(21.3)$ & $16(15.2)$ & $11(30.6)$ & 0.13 \\
\hline
\end{tabular}

Table 4 - Characteristics of parents and relatives of the patients with nonsyndromic cleft lip and/or palate.

\begin{tabular}{lcccc}
\hline & $\begin{array}{c}\text { Cleft lip } \\
\text { n (\%) }\end{array}$ & $\begin{array}{c}\text { Cleft lip and palate } \\
n(\%)\end{array}$ & $\begin{array}{c}\text { Cleft palate } \\
n(\%)\end{array}$ & $p$ value \\
Consanguinity & & & & \\
No & $45(95.7)$ & $100(95.2)$ & $34(94.4)$ & \\
Yes & $2(4.3)$ & $5(4.8)$ & $2(5.6)$ & 0.96 \\
\hline Miscarriage & & & & \\
No & $43(91.5)$ & $98(93.3)$ & $35(97.2)$ & \\
Yes & $4(8.5)$ & $7(6.7)$ & $1(2.8)$ & 0.56 \\
\hline Stillbirth & & & & \\
No & $45(95.7)$ & $102(97.1)$ & $36(100)$ & \\
Yes & $2(4.3)$ & $3(2.9)$ & 0 & 0.48 \\
\hline Orofacial cleft in 19t degree & & & & \\
relative & & & & \\
No & $37(78.7)$ & $80(76.2)$ & $28(77.8)$ & \\
Yes & $10(21.3)$ & $25(23.8)$ & $8(22.2)$ & 0.93 \\
\hline Cancer in 19t degree relative & & & & \\
No & $30(63.8)$ & $74(70.5)$ & $20(55.6)$ & \\
Yes & $17(36.2)$ & $31(29.5)$ & $16(44.4)$ & 0.24 \\
\hline
\end{tabular}

use of vitamins containing folic acid during the early pregnancy may decrease risk of NSCL/ $\mathrm{P}^{46,47}$. Additionally, variations on genes related to absorption, transport and metabolism of vitamins may have key roles in NSCL/P predisposition ${ }^{48}$.
Regarding family recurrence, 43 (29\%) patients had a family history of NSCL/P among first-degree relatives with little variation among cleft types. This is similar to other studies where a prevalence of oral clefts in other family members was found to range between $18 \%$ and $30.5 \%$. Furthermore, the finding that CLO patients were less likely to have a positive family history of oral clefts than patients with CLP and CPO was consistent with Grosen et al. $(2010)^{50}$. Akin marriages are an important factor in the development of a host of genetic anomalies as well as increased risk of oral cleft $\mathrm{ft}^{34,51}$. The akin relationships observed in the present study $(4.9 \%)$ were slightly more common than what was observed by Leite and Koifman (2009) $)^{52}$. In addition to the congenital anomalies, the consanguinity is also associated with increased risks of low birth weight, preeclampsia, which in turn are risk factors for stillbirth, especially preterm stillbirth ${ }^{51}$. In this study, the frequency of miscarriage and stillbirth was of $6 \%$ and $2.4 \%$ respectively, which are quite similar to average population. This study also revealed that cancer frequency in relatives of patients born with oral clefts ranged from 29.5 to $44.4 \%$. These findings agree with previous studies which suggested that individuals born with NSCL/P have a higher risk for cancer ${ }^{18,19,53}$. Recent evidences from genetic studies have supported the hypothesis that some genes are simultaneously associated with cancer and craniofacial disorders $^{21,22}$, but more studies are required to better understand which common mechanisms have a role in both conditions.

In summary, this study observed a CLP prevalence, followed by CLO and CPO. The clefts were more frequent in males than in females. Clefts were more frequent as unilateral and bilateral involvement prevailed in CLP. Complete clefts were significantly more common in CLP compared to CLO and CPO. The most common systemic alterations were in the otorhinolaryngologic system and respiratory tract, and the lack of vitamin supplementation as well as cigarette smoking, alcohol consumption and pesticide exposure were frequent environmental factors. Further studies focusing on specific environmental and genetic factors are required to facilitate health-related policies of resource use as well as oral cleft prevention and care.

\section{References}

1. Leslie EJ, Marazita ML. Genetics of cleft lip and cleft palate. Am J Med Genet C Semin Med Genet. 2013 Nov;163C(4):246-58. doi: 10.1002/ ajmg.c.31381.

2. Mossey PA, Little J, Munger RG, Dixon MJ, Shaw WC. Cleft lip and palate. Lancet. 2009 Nov 21;374(9703):1773-85. doi: 10.1016/S01406736(09)60695-4

3. Dixon MJ, Marazita ML, Beaty TH, Murray JC. Cleft lip and palate: understanding genetic and environmental influences. Nat Rev Genet. 2011 Mar;12(3):167-78. doi: 10.1038/nrg2933.

4. Marazita ML, Field LL, Cooper ME, Tobias R, Maher BS, Peanchitlertkajorn $S$, et al. Genome scan for loci involved in cleft lip with or without cleft palate, in Chinese multiplex families. Am J Hum Genet. 2002 Aug;71(2):349-64.

5. Martelli-Junior H, Porto LV, Martelli DR, Bonan PR, Freitas AB, Della Coletta R. Prevalence of nonsyndromic oral clefts in a reference hospital in the state of Minas Gerais, Brazil, between 2000-2005. Braz Oral Res. 
2007 Oct-Dec;21(4):314-7.

6. Rodrigues K, Sena MF, Roncalli AG, Ferreira MA. Prevalence of orofacial clefts and social factors in Brazil. Braz Oral Res. 2009 JanMar;23(1):38-42.

7. Marazita ML, Field LL, Cooper ME, Tobias R, Maher BS, Peanchitlertkajorn $\mathrm{S}$, et al. Nonsyndromic cleft lip with or without cleft palate in China: assessment of candidate regions. Cleft Palate Craniofac J. 2002 Mar;39(2):149-56.

8. Mangold E, Ludwig KU, Nothen MM. Breakthroughs in the genetics of orofacial clefting. Trends Mol Med. 2011 Dec;17(12):725-33. doi: 10.1016/j.molmed.2011.07.007.

9. Machado RA, Moreira HS, de Aquino SN, Martelli-Junior H, de Almeida Reis SR, Persuhn DC, et al. Interactions between RAD51 rs1801321 and maternal cigarette smoking as risk factor for nonsyndromic cleft lip with or without cleft palate. Am J Med GenetA. 2016 Feb;170A(2):536-9. doi: 10.1002/ajmg.a.37281.

10. Wehby GL, Murray JC. Folic acid and orofacial clefts: a review of the evidence. Oral Dis. 2010 Jan;16(1):11-9. doi: 10.1111/j.16010825.2009.01587.x.

11. Jia ZL, Shi B, Chen CH, Shi JY, Wu J, Xu X. Maternal malnutrition, environmental exposure during pregnancy and the risk of non-syndromic orofacial clefts. Oral Dis. 2011 Sep;17(6):584-9. doi: 10.1111/j.16010825.2011.01810.x.

12. Zhang $B$, Jiao $X$, Mao $L$, Xue J. Maternal cigarette smoking and the associated risk of having a child with orofacial clefts in China: a casecontrol study. J Craniomaxillofac Surg. 2011 Jul;39(5):313-8. doi: 10.1016/j.jcms.2010.07.005.

13. Boyles AL, Wilcox AJ, Taylor JA, Meyer K, Fredriksen A, Ueland PM, et al. Folate and one-carbon metabolism gene polymorphisms and their associations with oral facial clefts. Am J Med Genet A. 2008 Feb 15;146A(4):440-9. doi: 10.1002/ajmg.a.32162.

14. Mills JL, Molloy AM, Parle-McDermott A, Troendle JF, Brody LC, Conley $M R$, et al. Folate-related gene polymorphisms as risk factors for cleft lip and cleft palate. Birth Defects Res AClin Mol Teratol. 2008 Sep;82(9):63643. doi: 10.1002/bdra.20491.

15. Butali A, Little J, Chevrier C, Cordier S, Steegers-Theunissen R, Jugessur $A$, et al. Folic acid supplementation use and the MTHFR C677T polymorphism in orofacial clefts etiology: An individual participant data pooled-analysis. Birth Defects Res A Clin Mol Teratol. 2013 Aug;97(8):509-14. doi: 10.1002/bdra.23133

16. Wehby $\mathrm{GL}$, Cassell $\mathrm{CH}$. The impact of orofacial clefts on quality of life and healthcare use and costs. Oral Dis. 2010 Jan;16(1):3-10. doi: 10.1111/j.1601-0825.2009.01588.x.

17. Andrade Filho PA, Letra A, Cramer A, Prasad JL, Garlet GP, Vieira AR, et al. Insights from studies with oral cleft genes suggest associations between WNT-pathway genes and risk of oral cancer. J Dent Res. 2011 Jun;90(6):740-6. doi: 10.1177/0022034511401622.

18. Vieira AR, Khaliq $S$, Lace $B$. Risk of cancer in relatives of children born with isolated cleft lip and palate. Am J Med Genet A. 2012 Jun;158A(6):1503-4. doi: 10.1002/ajmg.a.35359.

19. Bille C, Winther JF, Bautz A, Murray JC, Olsen J, Christensen K. Cancer risk in persons with oral cleft--a population-based study of 8,093 cases. Am J Epidemiol. 2005 Jun 1;161(11):1047-55.

20. Goncalves E, Martelli DR, Coletta RD, Vieira AR, Caldeira AP, Martelli H, $\mathrm{Jr}$. Risk of leukemia in first degree relatives of patients with nonsyndromic cleft lip and palate. Braz Oral Res. 2014;28:1-3.

21. Li S, Wang C, Liu X, Hua S. The roles of AXIN2 in tumorigenesis and epigenetic regulation. Fam Cancer. 2015 Jun;14(2):325-31. doi: 10.1007/ s10689-014-9775-7.

22. Saboia TM, Reis MF, Martins AM, Romanos HF, Tannure PN, Granjeiro JM, et al. DLX1 and MMP3 contribute to oral clefts with and without positive family history of cancer. Arch Oral Biol. 2015 Feb;60(2):223-8. doi: 10.1016/j.archoralbio.2014.10.002.

23. Spina V, Psillakis JM, Lapa FS, Ferreira MC. [Classification of cleft lip and cleft palate. Suggested changes]. Rev Hosp Clin Fac Med Sao Paulo. 1972 Jan-Feb;27(1):5-6. [Portuguese].

24. Parra FC, Amado RC, Lambertucci JR, Rocha J, Antunes CM, Pena SD. Color and genomic ancestry in Brazilians. Proc Natl Acad Sci U S A. 2003 Jan 7;100(1):177-82.

25. Hao $Y$, Tian S, Jiao X, Mi N, Zhang B, Song T, et al. Association of Parental Environmental Exposures and Supplementation Intake with Risk of Nonsyndromic Orofacial Clefts: A Case-Control Study in Heilongjiang Province, China. Nutrients. 2015 Aug 27;7(9):7172-84. doi: 10.3390/ nu7095328.

26. Lithovius RH, Ylikontiola LP, Harila V, Sandor GK. A descriptive epidemiology study of cleft lip and palate in Northern Finland. Acta Odontol Scand. 2014 Jul;72(5):372-5. doi: 10.3109/00016357.2013.840737.

27. Christensen K, Juel K, Herskind AM, Murray JC. Long term follow up study of survival associated with cleft lip and palate at birth. BMJ. 2004 Jun 12;328(7453):1405.

28. Conway JC, Taub PJ, Kling R, Oberoi K, Doucette J, Jabs EW. Ten-year experience of more than 35,000 orofacial clefts in Africa. BMC Pediatr. 2015 Feb 14;15:8. doi: 10.1186/s12887-015-0328-5.

29. Martelli DR, Machado RA, Swerts MS, Rodrigues LA, Aquino SN, Martelli Junior $\mathrm{H}$. Non syndromic cleft lip and palate: relationship between sex and clinical extension. Braz J Otorhinolaryngol. 2012 Oct;78(5):116-20.

30. Kianifar H, Hasanzadeh N, Jahanbin A, Ezzati A. Cleft lip and Palate: A30year Epidemiologic Study in North-East of Iran. Iran J Otorhinolaryngol. 2015 Jan;27(78):35-41.

31. Cuozzo FD, Espinosa MM, da Silva KT, de Barros YB, Bandeca MC, Aranha AM, et al. Cleft lip and palate in a Brazilian subpopulation. J Int Oral Health. 2013 Aug;5(4):15-20.

32. Martelli-Junior H, Bonan PR, Santos RC, Barbosa DR, Swerts MS, Coletta RD. An epidemiologic study of lip and palate clefts from a Brazilian reference hospital. Quintessence Int. 2008 Oct;39(9):749-52.

33. Freitas JA, Dalben Gda S, Santamaria M, Jr., Freitas PZ. Current data on the characterization of oral clefts in Brazil. Braz Oral Res. 2004 AprJun;18(2):128-33.

34. Esmail AH, Abdo MA, Krentz H, Lenz JH, Gundlach KK. Centre-based statistics of cleft lip with/without alveolus and palate as well as cleft palate only patients in Aden, Yemen. J Craniomaxillofac Surg. 2014 Jun;42(4):297-304. doi: 10.1016/j.jcms.2013.05.030.

35. Aras I, Dogan S. Comparative Evaluation of the Pharyngeal Airways and Related Soft Tissues of Unilateral and Bilateral Cleft Lip and Palate Patients with the Noncleft Individuals. Cleft Palate Craniofac J. 2015 Aug 6. [Epub ahead of print]

36. Garfinkle JS, King TW, Grayson BH, Brecht LE, Cutting CB. A 12-year anthropometric evaluation of the nose in bilateral cleft lip-cleft palate patients following nasoalveolar molding and cutting bilateral cleft lip and nose reconstruction. Plast Reconstr Surg. 2011 Apr;127(4):1659-67. doi: 10.1097/PRS.0b013e31820a64d7.

37. Robison JG, Otteson TD. Increased prevalence of obstructive sleep apnea in patients with cleft palate. Arch Otolaryngol Head Neck Surg. 2011 Mar;137(3):269-74. doi: 10.1001/archoto.2011.8. 
38. Razzaghi H, Dawson A, Grosse SD, Allori AC, Kirby RS, Olney RS, et al. Factors associated with high hospital resource use in a population-based study of children with orofacial clefts. Birth Defects Res A Clin Mol Teratol. 2015 Feb;103(2):127-43. doi: 10.1002/bdra.23356.

39. Calzolari E, Pierini A, Astolfi G, Bianchi F, Neville AJ, Rivieri F. Associated anomalies in multi-malformed infants with cleft lip and palate: An epidemiologic study of nearly 6 million births in 23 EUROCAT registries. Am J Med Genet A. 2007 Mar 15;143A(6):528-37.

40. Zhang Z, Fang S, Zhang Q, Chen L, Liu Y, Li K, et al. Analysis of complications in primary cleft lips and palates surgery. J Craniofac Surg. 2014 May;25(3):968-71. doi: 10.1097/SCS.0000000000000832.

41. Vlastos IM, Koudoumnakis E, Houlakis M, Nasika M, Griva M, Stylogianni E. Cleft lip and palate treatment of 530 children over a decade in a single centre. Int J Pediatr Otorhinolaryngol. 2009 Jul;73(7):993-7. doi: 10.1016/j.ijporl.2009.03.027.

42. Figueiredo JC, Ly S, Magee KS, Ihenacho U, Baurley JW, Sanchez-Lara PA, et al. Parental risk factors for oral clefts among Central Africans, Southeast Asians, and Central Americans. Birth Defects Res A Clin Mol Teratol. 2015 Oct;103(10):863-79. doi: 10.1002/bdra.23417.

43. Sabbagh HJ, Hassan MH, Innes NP, Elkodary HM, Little J, Mossey PA. Passive smoking in the etiology of non-syndromic orofacial clefts: a systematic review and meta-analysis. PLoS One. $2015 \mathrm{Mar}$ 11;10(3):e0116963. doi: 10.1371/journal.pone.0116963.

44. Wu T, Schwender H, Ruczinski I, Murray JC, Marazita ML, Munger $R G$, et al. Evidence of gene-environment interaction for two genes on chromosome 4 and environmental tobacco smoke in controlling the risk of nonsyndromic cleft palate. PLoS One. 2014 Feb 6;9(2):e88088. doi: 10.1371/journal.pone.0088088.

45. McKinney CM, Chowchuen B, Pitiphat W, Derouen T, Pisek A, Godfrey K. Micronutrients and oral clefts: a case-control study. J Dent Res. 2013 Dec;92(12):1089-94. doi: 10.1177/0022034513507452.

46. Figueiredo RF, Figueiredo N, Feguri A, Bieski I, Mello R, Espinosa M, et al. The role of the folic acid to the prevention of orofacial cleft: an epidemiological study. Oral Dis. 2015 Mar;21(2):240-7. doi: 10.1111/ odi.12256.

47. Molina-Solana R, Yanez-Vico RM, Iglesias-Linares A, Mendoza-Mendoza A, Solano-Reina E. Current concepts on the effect of environmental factors on cleft lip and palate. Int J Oral Maxillofac Surg. 2013 Feb;42(2):177-84. doi: 10.1016/j.jom.2012.10.008.

48. de Aguiar PK, Coletta RD, de Oliveira AM, Machado RA, Furtado PG, de Oliveira LA, et al. rs1801133C >T polymorphism in MTHFR is a risk factor for nonsyndromic cleft lip with or without cleft palate in the Brazilian population. Birth Defects Res A Clin Mol Teratol. 2015 Apr;103(4):292-8. doi: $10.1002 /$ bdra.23365.

49. Ravichandran K, Shoukri M, Aljohar A, Shazia NS, Al-Twaijri Y, Al Jarba I. Consanguinity and occurrence of cleft lip/palate: a hospital-based registry study in Riyadh. Am J Med Genet A. 2012 Mar;158A(3):541-6. doi: 10.1002/ajmg.a.34432.

50. Grosen D, Chevrier C, Skytthe A, Bille C, Molsted K, Sivertsen A, et al. A cohort study of recurrence patterns among more than 54,000 relatives of oral cleft cases in Denmark: support for the multifactorial threshold model of inheritance. J Med Genet. 2010 Mar;47(3):162-8. doi: 10.1136/ jmg.2009.069385.

51. Maghsoudlou S, Cnattingius S, Aarabi M, Montgomery SM, Semnani S, Stephansson O, et al. Consanguineous marriage, prepregnancy maternal characteristics and stillbirth risk: a population-based case-control study. Acta Obstet Gynecol Scand. 2015 Oct;94(10):1095-101. doi: 10.1111/ aogs. 12699

52. Leite IC, Koifman S. Oral clefts, consanguinity, parental tobacco and alcohol use: a case-control study in Rio de Janeiro, Brazil. Braz Oral Res. 2009 Jan-Mar;23(1):31-7.

53. Menezes R, Marazita ML, Goldstein McHenry T, Cooper ME, Bardi K, Brandon $\mathrm{C}$, et al. AXIS inhibition protein 2, orofacial clefts and a family history of cancer. J Am Dent Assoc. 2009 Jan;140(1):80-4. 